\title{
"The impact of global financial transformations on the economic security of Central and Eastern European countries"
}

\begin{tabular}{|c|c|}
\hline AUTHORS & $\begin{array}{l}\text { Olena Bulatova (Dttps://orcid.org/0000-0001-7938-7874 } \\
\text { Tetyana Marena (D https://orcid.org/0000-0002-7970-4005 } \\
\text { Yurii Chentukov (D https://orcid.org/0000-0002-7878-7769 } \\
\text { Tetiana Shabelnyk (D) https://orcid.org/0000-0001-9798-391X }\end{array}$ \\
\hline ARTICLE INFO & $\begin{array}{l}\text { Olena Bulatova, Tetyana Marena, Yurii Chentukov and Tetiana Shabelnyk } \\
\text { (2020). The impact of global financial transformations on the economic security of } \\
\text { Central and Eastern European countries. Public and Municipal Finance, 9(1), 1- } \\
\text { 13. doi:10.21511/pmf.09(1).2020.01 }\end{array}$ \\
\hline DOI & http://dx.doi.org/10.21511/pmf.09(1).2020.01 \\
\hline RELEASED ON & Friday, 10 July 2020 \\
\hline RECEIVED ON & Monday, 11 May 2020 \\
\hline ACCEPTED ON & Tuesday, 23 June 2020 \\
\hline LICENSE & $\begin{array}{l}(c)) E Y \\
\text { This work is licensed under a Creative Commons Attribution } 4.0 \text { International } \\
\text { License }\end{array}$ \\
\hline JOURNAL & "Public and Municipal Finance" \\
\hline ISSN PRINT & $2222-1867$ \\
\hline ISSN ONLINE & $2222-1875$ \\
\hline PUBLISHER & LLC "Consulting Publishing Company "Business Perspectives" \\
\hline FOUNDER & LLC "Consulting Publishing Company "Business Perspectives" \\
\hline
\end{tabular}

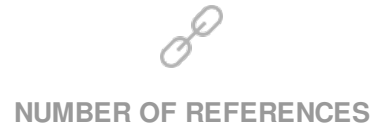

27
NUMBER OF FIGURES

2

\section{E=-}

NUMBER OF TABLES

4

(C) The author(s) 2021. This publication is an open access article. 


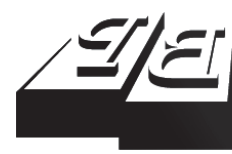

BUSINESS PERSPECTIVES

(2)

LLC "CPC "Business Perspectives" Hryhorii Skovoroda lane, 10, Sumy, 40022, Ukraine www.businessperspectives.org

Received on: $11^{\text {th }}$ of May, 2020 Accepted on: $23^{\text {rd }}$ of June, 2020 Published on: $10^{\text {th }}$ of July, 2020

๑) Olena Bulatova, Tetyana Marena, Yurii Chentukov, Tetiana

Shabelnyk, 2020

Olena Bulatova, Doctor of Economics, Professor, Mariupol State University of the Ministry of Education and Science of Ukraine, Mariupol, Ukraine.

Tetyana Marena, Ph.D., Associate Professor, Mariupol State University of the Ministry of Education and Science of Ukraine, Mariupol, Ukraine. (Corresponding author)

Yurii Chentukov, Doctor of Economics, Professor, Mariupol State University of the Ministry of Education and Science of Ukraine, Mariupol, Ukraine.

Tetiana Shabelnyk, Doctor of Economics, Associate Professor Mariupol State University of the Ministry of Education and Science of Ukraine, Mariupol, Ukraine.
Olena Bulatova (Ukraine), Tetyana Marena (Ukraine), Yurii Chentukov (Ukraine), Tetiana Shabelnyk (Ukraine)

\section{THE IMPACT OF GLOBAL FINANCIAL TRANSFORMATIONS ON THE ECONOMIC SECURITY OF CENTRAL AND EASTERN EUROPEAN COUNTRIES}

\begin{abstract}
Global financial transformations provoke shifts in financial systems that can threaten countries' economic security. Further integration of the CEE states to the global economy will be accompanied by the increasing dependence of their financial markets and economic security on global financial challenges. The study aims to identify the relationship between global and regional financial trends that shape CEE countries' economic security and reveal the shifts in the CEE region's economic security under the influence of global financial transformation. The global financial transformations are the object of the study. Comparative analysis of the dynamics of financial transformations in the world and the CEE countries is made using structural analysis and methods of economic and mathematical modeling of trends. Given the heterogeneity of the CEE states' financial development, global financial transformations have different manifestations in these countries. The relationship between global and regional indicators of financial transformation proved to be ambiguous. The regional dynamics of stock market capitalization, debt securities, and external debt fit corresponding world indicators' dynamics. The indicators of global and regional official reserves and bank assets are moving in different directions. The region's economic security challenges are great volatility of stock market capitalization, growth of external debt burden, and uneven distribution of official reserves. The obtained results should be considered when identifying financial threats affecting the CEE countries' security and developing relevant policies for shaping the region's efficient financial system.
\end{abstract}

Keywords

global financial transformations, economic security, financial market, financial assets, financial depth, global financial crisis

JEL Classification F30, F52

\section{INTRODUCTION}

The current state of international and national economic security is increasingly affected by globalization processes. One of the most controversial and dynamic components of globalization is financial globalization, which qualitatively changes financial systems and markets, and therefore the financial component of the international security environment. Given that financial resources are the most globalized resources of the world economy today, the financial environment is the area of shaping the factors and threats to the country's economic security that can rapidly expand outside the national economy. With the onset of globalization, the financial sector's predisposition to "contagion" effect has grown over the years, and financial shocks (especially in countries where financial sectors are important to the global financial system) can entail regional and global implications, a demonstrative example of which is the global economic crisis of 2008-2009. 
The economies of Central and Eastern Europe have been undergoing profound transformations for several decades. In market transformation, the region's financial sector has experienced major structural reforms, including privatization, liberalization, and attraction of foreign capital. Alongside it, the CEEC group remains highly differentiated in terms of the national economies' development. Eleven of twelve countries in the region (except Albania) are member states of the European Union. Besides, five countries (Estonia, Latvia, Lithuania, Slovakia, and Slovenia) are members of the Eurozone. Poland, Hungary, and the Czech Republic are considered the region's leaders in economic development. At the same time, international organizations still consider the financial markets of seven CEE countries (Albania, Bulgaria, Croatia, the Czech Republic, Hungary, Poland, and Romania) as the emerging markets. The empirical experience of emerging financial markets functioning shows that they are typically characterized by greater volatility in core indicators and higher financial transaction risks. Due to the unpredictability of CEE countries' financial markets, they are more attractive to speculative transactions than to long-term investors.

Thus, on the one hand, CEE countries are an integral part of the European community of advanced economies, and on the other hand, the financial markets of these countries are not so integrated into the world financial system as, for instance, some Western European economies, and are still of a mixed type, showing some features of emerging markets. Under such circumstances, the trajectory of financial sector development in CEE countries under the influence of global financial transformations can be unpredictable, causing serious problems that threaten the region's economic security.

\section{LITERATURE REVIEW}

When studying the international security environment, the scientists emphasize that global factors increasingly influence the countries' national economic security (Buzan, 1991; Dudin et al., 2018). In particular, experts from the National Institute for Strategic Studies (Ukraine) point out that globalization processes determine the major trends in global and national economies and lead to dramatic changes in the international security environment (Parakhonskyi, Yavorska, \& Reznikova, 2013). Globalization entails a transformation of factors and threats to security. Among the factors that can threaten countries' security and are classified by the extent of their spread as global, regional, and local, global factors' significance is increasing. Besides, actual security threats are described as "hard" ("hard" security includes military and defense aspects of the national security) and "soft" ("soft" security focuses on political, social and economic challenges to national security) (Parakhonskyi et al., 2013; Herd \& Aldis, 2005). Against the background of globalization, the importance and impact of "soft" security threats, including economic factors, is steadily increasing.

Studies on economic and financial development and the CEE countries' security challenges are mainly concentrated in two separate areas. On the one hand, the scientists' attention is focused on ensuring the national security of CEE countries and the region. Swieżak (2012) studies the international challenges to the regional security of the CEE countries and Poland's national security, particularly focusing not so much on economic factors but the geopolitical, social, and military challenges affecting the regional security environment. Simultaneously, the author acknowledges that the global economic crisis, sharpening several trends and problems of the international environment, acts not only as a threat to economic security but also enables to introduce new ideas in the security sphere. Assessing the current security environment of Poland, the experts of the Ministry of National Defense note that global trends largely determine the shape that the challenges and threats to national security take on. In particular, the dissonance between globalization and national interests is becoming more prominent in many aspects (Ministry of National Defense of Poland, n.d.).

Besides, the scientific achievements in security include identifying and studying the components of CEE countries' national security. Bocka, Jocic, Petrovics, and Tsanov (2007) identify three major aspects of security for Central European coun- 
tries: the destabilizing role of Russia for the region; aggravation of threats to energy security; international terrorism, organized crime, and weak governance. Tumkevič (2016) notes that cybersecurity is increasingly viewed as a matter of concern at all levels of society and needs to be addressed at the national level; therefore, ensuring the security of cyberspace is a top national security priority for most states. Based on a study of the strategies and institutional structure of cybersecurity in some countries of Central and Eastern Europe, the author concludes that the cybersecurity strategies of the countries of the region are becoming more integrated and inclusive; they address cybersecurity comprehensively and cover economic, social, legal, law enforcement, military and other aspects of cybersecurity.

On the other hand, scientific sources provide the results of studies devoted to forming financial systems and developing financial markets in CEE countries. Balling, Lierman, and Mullineux (2004) presenting the results of a study of the reforms that the CEE financial sectors and markets have undergone during the transition period focus on the implications of the World Bank and IMF policies in the region.

The study of Schröder (2001) is devoted to multidimensional analysis of the financial sector functioning in the most developed countries of Central and Eastern Europe, including the issues of institutionalization of the region's financial markets, assessment of market efficiency and international integration of stock markets. A significant part of the research relates to changes in the financial sector in CEE countries related to EU membership, including the impact of accession to the EU on monetary and foreign exchange policy, corporate finance, and stock exchange development. Matousek (2010), based on assessing the development of the financial markets in the CEE transition economies and the effects of the global economic crisis on national financial sectors, emphasizes key obstacles to fully integrating countries' financial markets to the EU financial space.

Gardó and Martin (2010) assess the strengths and vulnerabilities of the CEE countries' financial systems on the eve of the global economic and financial crisis. Studying the influence of the crisis on the region's financial system, the authors conclude that the impact of the global crisis on the financial sectors of the CEE countries is rather heterogeneous, and the countries having the largest economic imbalances tend to be most affected by the crisis. The ability of governments to use economic policy instruments to counteract the real effects of the crisis has also proved to be heterogeneous and, in particular, depended on the current exchange rate regime and the initial fiscal positions.

The study of Orylski (2009) presents a scenario for the development of capital markets in Central and Eastern Europe and identifies factors affecting the region's financial markets' development. Based on a comparison of the key indicators of the capital market in CEE and the leading developed countries, the author identifies capital market consolidation as a possible way to achieve the optimum level of its development and ensure its support for the economy's real sector.

Cevik, Dibooglu, and Kutan (2016), while systematizing scientific approaches to financial sector study in CEE countries, focus on banking system research and the impact of financial market integration on the spread of financial crises. The authors point out that, traditionally, "foreign bank ownership is associated with higher banking efficiency" and such institutions demonstrate better performance compared to the domestic bank ownership; however, the presence of foreign banks in the financial system is compounded by the risks of volatility transmission from leading European financial markets. At the same time, the authors argue that the global financial crisis of 2008-2009 has significantly affected these and other patterns of financial sector development in the countries.

Bayar, Akyuz, and Erem (2017) studied the interaction between economic openness indicators (particularly openness of trade and financial markets) and financial development in nine Central and Eastern European countries. They have concluded that the openness of commodity markets has had a positive impact on the development of the financial sector of all countries in the region in the long run. In contrast, the nature of the impact of financial markets' openness on the level of financial development is different across countries. 
According to Redo (2018), the countries of Central and Eastern Europe are rather integrated into the international economic and financial systems, which entails their dependence on foreign capital and the situation on global markets, makes them vulnerable to external shocks and threatens the financial security of their economies.

Studying the potential of the capital market in Central and Eastern Europe, Silvestri (2019) notes that, due to several barriers and unresolved problems, capital markets in the region lag behind the more developed markets of Western Europe. In particular, CEE countries' stock and bond markets are relatively small compared to Western European countries that are the EU member states. To solve the problems of national capital markets functioning, countries of the region should diversify their sources of economic development financing, provide better access to financing for small and medium-sized enterprises, and improve financial supervision systems to increase investors' confidence.

Based on the results of the study of Eastern European financial services market and analysis of the composition and the number of financial institutions, Ukrainian and Polish scholars offer a model of the impact of different financial services sectors on the formation of financial assets of the respective countries (Shkarlet, Dubyna, Vovk, \& Noga, 2019). The authors emphasize the importance of banking institutions' role in the economic development of the region's countries compared to other types of financial intermediaries.

A review of current research on the CEE countries' economic security issues shows that national security is analyzed mainly in terms of political and military aspects, and economic security studies focus on its components (energy, cybersecurity, etc.). However, with the increasing importance of the economic component of national security, on the one hand, and growing impact of global financial trends on the international and national security environment, on the other hand, the studies on determining the nature of the financial trends displays in Central and Eastern Europe and identifying the features of the global financial transformations impact on the economic security of the countries of the region are becoming increasingly important and relevant.

\section{AIMS}

This study aims at determining the global financial factors that impact the economic security of Central and Eastern European countries, identifying the relationship between global and regional indicators that characterize financial transformations, and justifying the nature of changes that occur in the economic security of CEE countries under the influence of global financial transformations.

\section{METHODS}

Existing approaches to countries' grouping and different statistical databases include different countries in the CEE group. In this study, the Organization for Economic Cooperation and Development's approach was used to form a sample of Central and Eastern European countries. Central and Eastern Europe (CEE) is a term used by the OECD for a group of countries including Albania, Bulgaria, Croatia, the Czech Republic, Hungary, Poland, Romania, the Slovak Republic, Slovenia, and three Baltic countries: Estonia, Latvia, and Lithuania (Organization for Economic Cooperation and Development, n.d.).

To assess the positions of CEE countries in the global financial system and define the shifts in the structure of financial assets of the world and the CEE countries, the methods of structural analysis and statistical tools are applied. Comparative analysis of the dynamics of global financial transformations in the world and the CEE countries is made based on economic and mathematical modeling methods. In particular, to assess the degree and nature of the relationship between global and regional indicators characterizing financial factors of economic security formation, the methods of economic and mathematical modeling of trends are used. These methods are based on identifying and excluding a random component and a deterministic component containing a trend, a seasonal component, a cyclic component from the time series. A characteristic feature of the time series of any economic indicators is that essential information is contained in the measured items' numerical values and the order of their movement. Therefore, to identify the main trend in developing 
global and regional indicators of financial transformations without the influence of a random component, its smoothing is advisable. More reliable results of the time series smoothing can be achieved using analytical alignment methods. In this case, the actual levels are replaced by levels calculated based on a mathematical function, and the changing level is estimated as a function of time. The reliability of the constructed trend models of the global and regional indicators of financial transformations is verified by the coefficient of determination, reflecting the trend line values' closeness to the actual data.

Data on the dynamics of the following indicators are selected to characterize global financial transformations affecting the current international security environment: the size of financial assets, including stock market capitalization, debt securities, bank assets (world and CEE countries indicators); the ratio of external debt to GDP (for leading developed countries, developing economies and CEE countries on average); official international reserves (global and concentrated in the CEE countries).

\section{RESULTS AND DISCUSSION}

The current international security environment is operating in rapidly changing conditions, and national economic security systems are being shaped under the impact of a wide range of traditional and emerging security risks, both internal and external. Particular attention should be paid to global economic transformations as risk factors since, in recent times, their importance has sometimes been more significant than endogenous factors.

At the current stage of globalization transformations of the end of the XX century - beginning of the XXI century, the changes occurring in the world financial system and international financial markets transform into regularities. The most influential global financial factors that determine the current state of the international and national security environment include an increase in the level of financial depth of the global economy; the development of the global financial crisis and the high risks of its recurrence; general deterioration of the financial conditions of the world economy, the growing uncertainty of the global financial environment; increasing unevenness in the spatial distribution of global financial assets as a result of the intensification of competition for financial resources; instability of the structure of global financial assets by type of financial instruments; aggravation of external debt problems; increase in the heterogeneity of the countries' international liquidity and official reserves availability; the growing scale of illegal capital movement operations, etc.

Despite all the positive transformations that characterize CEE countries' financial markets as a result of their profound reform during the transition period, the countries of the group do not play a significant role in the redistribution of financial resources of the world: the share of these countries in global financial assets during 2007-2018 ranged from $0.5 \%$ to $0.9 \%$, averaging around $0.7 \%$ (for comparison: the share of CEE countries in world GDP decreased from $2.3 \%$ in 2007 to $1.9 \%$ in 2018). Therefore, the share of CEE countries in world production is ahead of their share in the world's financial assets. The level of financial development of CEE countries is also far behind the global level in terms of the indicator of the economy's financial depth, calculated as the ratio of financial assets to GDP (Figure 1).

For a long time, the financial sector has played a secondary role in the world and national economies, providing monetary and financial services to other sectors. Today, the situation has changed dramatically: financial markets have become an independent unit of the economic system, and financial transactions are often separated from transactions with real assets. An illustration of this is an increase in the global economy's financial depth, which has exceeded $400 \%$ in recent years. The widening gap between the economy's financial and real sectors once was one of the driving forces of the global financial crisis and is still a factor that causes an imbalance of the world economy and the corresponding deterioration of the security environment. In this sense, lower levels of CEE countries' financial depth than the global level of financialization may indicate that these countries are less tended to financial shocks due to the potentially smaller scale of "bubbles". 


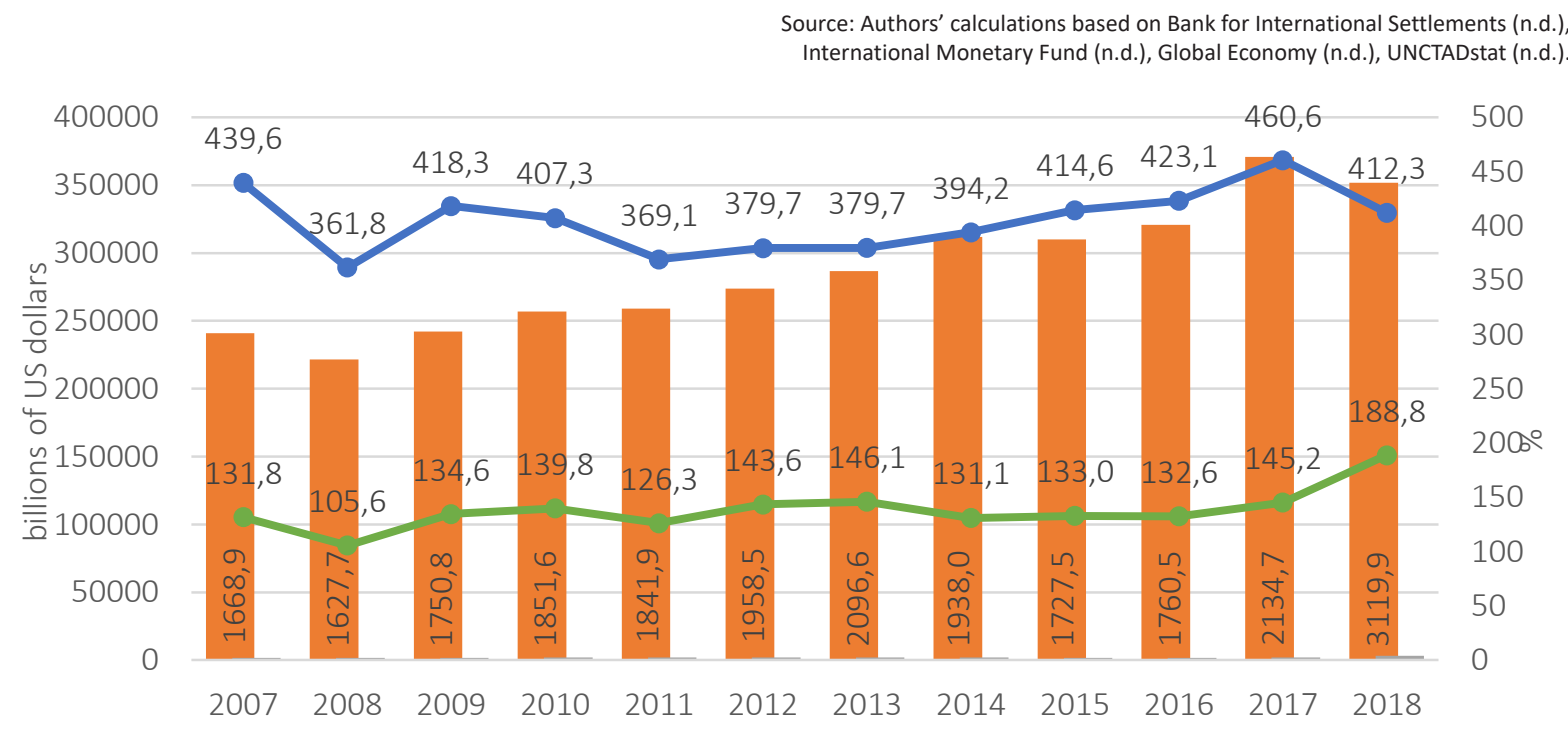

Global financial assets, billions of US dollars CEE financial assets, billions of US dollars

-Financial depth of world economy, \% —Financial depth of CEE economies, \%

Figure 1. Financial depth of the global and CEE economies in 2007-2018

Since the global financial crisis, and due to the increasing scale and uncontrollability of financial flows, there has been an overall increase in the global financial environment's uncertainty. This deterioration of financial conditions is felt not only by the financial markets of developing countries, which have traditionally been considered more subject to financial turmoil but also by developed financial systems. Moreover, the effects of the global financial crisis were particularly noticeable for countries whose financial sectors were more integrated into the global financial system and played an important role in it. However, a significant drawback of these countries' economic security systems was their inability to anticipate a financial shock of such magnitude and take precautionary measures. In this context, the low enough indicators characterizing the CEE financial sectors' involvement in the global financial market can indicate that they are less addicted to crisis "contagion", thereby contributing to their economic security.

Table 1. CEE countries' positions in the global financial system in 2007 and 2018, \%

Source: Authors' calculations based on Bank for International Settlements (n.d.), CEIC Data (n.d.), International Monetary Fund (n.d.), Global Economy (n.d.).

\begin{tabular}{|c|c|c|c|c|c|c|c|c|}
\hline \multirow{2}{*}{ Country } & \multicolumn{2}{|c|}{ Stock market capitalization } & \multicolumn{2}{|c|}{ Debt securities } & \multicolumn{2}{|c|}{ Bank assets } & \multicolumn{2}{|c|}{ Official reserves } \\
\hline & 2007 & 2018 & 2007 & 2018 & 2007 & 2018 & 2007 & 2018 \\
\hline Albania & $\mathrm{n} / \mathrm{a}$ & $\mathrm{n} / \mathrm{a}$ & $n / a$ & $\mathrm{n} / \mathrm{a}$ & 0.01 & 0.00 & 0.03 & 0.03 \\
\hline Bulgaria & 0.03 & 0.02 & 0.01 & 0.01 & 0.02 & 0.02 & 0.24 & 0.22 \\
\hline Croatia & 0.11 & 0.03 & 0.02 & 0.03 & 0.04 & 0.03 & 0.19 & 0.15 \\
\hline Czech Republic & 0.14 & 1.43 & 0.11 & 0.20 & 0.10 & 0.09 & 0.48 & 1.17 \\
\hline Estonia & 0.01 & 0.00 & 0.00 & 0.00 & 0.02 & 0.01 & 0.05 & 0.00 \\
\hline Hungary & 0.07 & 0.04 & 0.14 & 0.11 & 0.10 & 0.05 & 0.33 & 0.22 \\
\hline Latvia & 0.00 & 0.00 & 0.00 & 0.01 & 0.02 & 0.01 & 0.08 & 0.04 \\
\hline Lithuania & 0.01 & 0.01 & 0.01 & 0.02 & 0.02 & 0.01 & 0.11 & 0.04 \\
\hline Poland & 0.33 & 0.23 & 0.28 & 0.30 & 0.20 & 0.24 & 0.91 & 0.89 \\
\hline Romania & 0.05 & 0.05 & $\mathrm{n} / \mathrm{a}$ & $\mathrm{n} / \mathrm{a}$ & 0.05 & 0.04 & 0.55 & 0.35 \\
\hline Slovakia & 0.01 & 0.01 & 0.03 & 0.06 & 0.04 & 0.05 & 0.26 & 0.03 \\
\hline Slovenia & 0.04 & 0.01 & 0.02 & 0.03 & 0.04 & 0.02 & 0.01 & 0.01 \\
\hline Total & 0.80 & 1.83 & 0.62 & 0.77 & 0.66 & 0.57 & 3.24 & 3.15 \\
\hline
\end{tabular}


At the same time, globalization unequally affects the position of CEE countries in the world financial system in terms of individual indicators. Table 1 presents the data on CEE countries' share and groups in global indicators characterizing the stock market capitalization, debt securities, bank assets, and official international reserves.

The assessment of the intra-regional structure of countries' financial assets shows that CEE countries are significantly differentiated in terms of financial development. The greatest shares of the region's financial assets are in Poland (the country's average share in financial resources of the region was nearly 40\% in 2007-2018), the Czech Republic (19\%) and Hungary (19\%). Albania (0.4\%), Estonia (1.2\%) and Latvia (1.5\%) have the lowest level of financial assets. The average share of other countries of the region is in the range of $2-6 \%$.

Shifts in the positions of CEE countries in different segments of the global financial market are different. Within the analyzed period, there was a certain improvement in the CEE countries' position in the global stock market (the region's share of stock market capitalization in the world indicator increased from $0.8 \%$ to $1.83 \%$ ) and a slight increase in the countries' share in the total volume of debt securities (from $0.62 \%$ to $0.77 \%$ ). The share of CEE countries' bank assets in the global bank assets is almost stable, decreasing from $0.66 \%$ to $0.57 \%$. In terms of ensuring international liquidity as an important indicator of the country's financial and economic security, the positions of the CEE countries are to some extent better than in case of the previous indicators: the share of the region in the official global reserves exceeded 3\% during the analyzed period.

The shifts in CEE positions in the global financial system that have been occurring in recent years are associated both with the internal dynamics of countries' financial development indicators and the overall redistribution of financial assets that occurs in the global financial market and is accompanied by increased global competition for financial resources. The post-crisis transformation of the financial assets structure across the global regions is displayed in the European region's collapsing role, where CEE countries belong, in the distribution of global financial assets. In 2018, the
European region's financial markets accounted for nearly $25 \%$ of global financial assets, while in 2008 , their share was almost $41 \%$.

The volatility of the financial environment and large-scale uncontrolled use of financial instruments cause permanent shifts in the structure of the world's financial assets, and capital flows between financial market segments. This leads to the imbalances of the countries' financial markets' internal structure, increasing the instability of sources of economies financing, and threatening states' economic security. In terms of types of financial assets, the world, in general, is shifting towards bank lending: the share of bank assets in global financial assets has increased from $40 \%$ in 2007 to $51 \%$ in 2018 , accompanied by a corresponding reduction in the share of stock (from $27.0 \%$ to $19.5 \%$ ) and debt securities (from 33\% to 29\%) (Table 2).

Table 2. Structure of financial assets of the world and the CEE countries in 2007-2018, \%

Source: Authors' calculations based on Bank for International Settlements (n.d.), CEIC Data (n.d.), International Monetary Fund (n.d.).

\begin{tabular}{|c|c|c|c|c|c|c|}
\hline \multirow[t]{2}{*}{ Period } & \multicolumn{2}{|c|}{$\begin{array}{l}\text { Stock market } \\
\text { capitalization }\end{array}$} & \multicolumn{2}{|c|}{$\begin{array}{c}\text { Debt } \\
\text { securities }\end{array}$} & \multicolumn{2}{|c|}{ Bank assets } \\
\hline & world & CEE & world & CEE & world & CEE \\
\hline 2007 & 27.00 & 31.61 & 33.27 & 30.19 & 39.73 & 38.20 \\
\hline 2012 & 19.30 & 16.86 & 36.15 & 36.89 & 44.55 & 46.25 \\
\hline 2017 & 22.25 & 17.97 & 30.25 & 39.36 & 47.50 & 42.67 \\
\hline 2018 & 19.52 & 40.44 & 29.23 & 25.60 & 51.25 & 33.96 \\
\hline
\end{tabular}

In the pre-crisis period and the first post-crisis years, the structure of the financial assets of CEE countries was broadly in line with that of global financial assets. However, further changes in the financial markets of the region led to the appearance of differences between regional and global indicators of their structure. In particular, in 2017, the share of debt securities in the structure of CEE economies financing has increased slightly, in contrast to the overall global tendency of reducing the share of debt securities. Conversely, in contrast to the increase in the share of global bank assets, the share of bank financing of CEE economies decreased from $46.0 \%$ in 2012 to $42.7 \%$ in 2017. In 2018, this trend continued, and the share of bank assets in the region's financial resources fell to about $34 \%$. The size of CEE countries' bank assets has grown in absolute dimension, reaching 
in 2018, the historical maximum and amounting to about USD 1,060 billion. The significant redistribution of assets between the segments of the financial market took place due to the rapid increase in the stock market capitalization in the Czech Republic by the end of 2018 (18 times), which ratio to the country's GDP increased from 25\% to $399 \%$ per year. More than $40 \%$ of the region's financial assets are traded on the stock market today.

The increase in the role of bank lending and debt securities in financing economic development leads to an increase in global debt, which is becoming a considerable problem. According to the World Economic Forum (2019), the world economy's debt burden is estimated at $225 \%$ of GDP. Moreover, this indicator is much higher than in the pre-crisis period and is an influential factor threatening economic security. An uncontrolled increase in external debt ratios is particularly dangerous, as far as exchange rate volatility and high currency risks can entail a further increase in debt burden on the economies of borrowers. A high level of external debt and an increase in external debt ratios are traditionally characteristic of developed countries; the external debt burden on European countries' economies is particularly high (Table 3).
In terms of the external debt to GDP ratio, CEE countries are also highly different. The external debt burden in Romania, Bulgaria, Poland and Albania is relatively low; Hungary, Slovakia and Latvia are the most indebted economies. The general tendency of the external debt dynamics during the analyzed period is ambiguous: in half of the countries there is an increase in the level of debt, other countries are characterized by its decrease. It is significant that the average ratio of external debt to GDP in the CEE group is lower than in most of the leading developed countries.

An increase in the countries' external debt requires maintaining their international liquidity at the level necessary for external debt repayment and preventing debt crisis development. In terms of ensuring international liquidity, a positive tendency is an overall increase in official global reserves, which grew by 75\% from 2007 to 2018 . Meanwhile, increasing unevenness in the distribution of official reserves between countries and regions of the world is observed. Today, China holds the greatest international reserves, accounting for $25 \%$ of the world's official reserves $(21 \%$ in 2007). International reserve allocation is highly concentrated in the regional dimension: $49 \%$ of

Table 3. External debt to GDP ratio in selected developed economies and CEE countries, 2007-2018, \%

Source: Authors' calculations based on CEIC Data (n.d.), Global Economy (n.d.), World Bank Group (n.d.).

\begin{tabular}{|c|c|c|c|c|c|c|c|c|}
\hline Country & 2007 & 2009 & 2011 & 2013 & 2015 & 2017 & 2018 & Change \\
\hline \multicolumn{9}{|c|}{ Leading developed economies } \\
\hline UK & 366.9 & 369.3 & 372.5 & 314.8 & 286.8 & 308.9 & 307.0 & -59.9 \\
\hline France & 170.4 & 196.5 & 200.8 & 193.8 & 209.2 & 208.8 & 216.4 & +46.0 \\
\hline Germany & 147.3 & 153.9 & 163.1 & 150.7 & 150.9 & 146.5 & 144.7 & -2.6 \\
\hline Australia & 94.0 & 97.9 & 94.2 & 107.7 & 129.0 & 118.9 & 122.1 & +28.1 \\
\hline Canada & 57.3 & 73.2 & 75.8 & 84.8 & 113.3 & 115.6 & 121.7 & +64.4 \\
\hline USA & 92.9 & 94.6 & 99.8 & 98.2 & 97.2 & 97.6 & 96.4 & +3.5 \\
\hline Japan & 37.9 & 39.2 & 49.3 & 59.0 & 67.1 & 74.6 & 81.0 & +43.1 \\
\hline \multicolumn{9}{|c|}{ CEE countries } \\
\hline Latvia & 127.7 & 154.7 & 146.0 & 133.9 & 143.7 & 140.5 & 121.0 & -6.7 \\
\hline Slovakia & 57.3 & 78.3 & 78.3 & 82.1 & 85.2 & 107.8 & 113.0 & +55.7 \\
\hline Hungary & 118.8 & 172.5 & 180.2 & 144.4 & 130.9 & 102.6 & 100.5 & -18.3 \\
\hline Slovenia & 101.7 & 114.9 & 112.4 & 114.2 & 120.0 & 101.9 & 92.0 & -9.7 \\
\hline Czech Republic & 41.4 & 49.8 & 57.3 & 66.7 & 67.9 & 86.6 & 81.7 & +40.4 \\
\hline Croatia & 89.8 & 110.3 & 101.8 & 114.7 & 106.4 & 94.8 & 80.5 & -9.3 \\
\hline Lithuania & 72.1 & 86.7 & 80.5 & 70.9 & 76.8 & 83.9 & 78.5 & +6.4 \\
\hline Estonia & 106.1 & 121.1 & 99.4 & 92.5 & 92.2 & 83.1 & 76.4 & -29.8 \\
\hline Albania & 28.7 & 41.5 & 53.5 & 66.2 & 74.4 & 68.7 & 65.2 & +36.5 \\
\hline Poland & 47.9 & 58.3 & 70.7 & 69.8 & 71.8 & 67.0 & 64.0 & +16.1 \\
\hline Bulgaria & 89.4 & 101.3 & 87.9 & 88.2 & 74.8 & 66.2 & 60.1 & -29.3 \\
\hline Romania & 46.0 & 65.7 & 75.7 & 68.2 & 57.4 & 51.9 & 49.2 & +3.2 \\
\hline Average per group & 77.2 & 96.2 & 95.3 & 92.6 & 91.8 & 87.9 & 81.8 & +4.6 \\
\hline
\end{tabular}


Table 4. Trend models of global and regional financial indicators

Source: Authors' calculations.

\begin{tabular}{|c|c|c|c|}
\hline No. & Indicator & Trend model & $R^{2}$ \\
\hline 1 & $\begin{array}{l}\text { Stock market capitalization, USD } \\
\text { billion (world) }\end{array}$ & $y=2.4351 x^{6}-110.73 x^{5}+1960.8 x^{4}-17140 x^{3}+77009 x^{2}--161956 x+163956$ & 0.8613 \\
\hline 2 & $\begin{array}{l}\text { Stock market capitalization, USD } \\
\text { billion (CEE) }\end{array}$ & $y=0.0794 x^{6}-2.9353 x^{5}+42.925 x^{4}-314.49 x^{3}+1198.7 x^{2}-2201.2 x+1799.5$ & 0.9905 \\
\hline 3 & Debt securities, USD billion (world) & $y=-4.2291 x^{6}+150.39 x^{5}-2012.4 x^{4}+12689 x^{3}-39347 x^{2}+60731 x+47495$ & 0.9475 \\
\hline 4 & Debt securities, USD billion (CEE) & $y=-0.0502 x^{6}+1.8979 x^{5}-27.238 x^{4}+185.14 x^{3}-608.27 x^{2}+917.75 x+22.752$ & 0.8706 \\
\hline 5 & Bank assets, USD billion (world) & $y=8105.4 x+80547$ & 0.9488 \\
\hline 6 & Bank assets, USD billion (CEE) & $y=-0.0417 x^{6}+1.7349 x^{5}-27.917 x^{4}+219.52 x^{3}-880.29 x^{2}+1705.3 x-376.43$ & 0.9256 \\
\hline 7 & $\begin{array}{l}\text { External debt, \% of GDP (leading } \\
\text { developed economies) }\end{array}$ & $y=0.0002 x^{5}-0.0196 x^{4}+0.4814 x^{3}-4.4717 x^{2}+16.947 x+119.88$ & 0.7923 \\
\hline 8 & $\begin{array}{l}\text { External debt, \% of GDP (developing } \\
\text { economies) }\end{array}$ & $y=0.0004 x^{6}-0.0173 x^{5}+0.2695 x^{4}-2.0435 x^{3}+7.8629 x^{2}-14.237 x+35.726$ & 0.7590 \\
\hline 9 & External debt, \% of GDP (CEE) & $y=-0.0182 x^{4}+0.5258 x^{3}-5.6001 x^{2}+25.1 x+56.067$ & 0.9351 \\
\hline 10 & $\begin{array}{l}\text { Official reserves, billions of US dollars } \\
\text { (world) }\end{array}$ & $y=-85.292 x^{2}+1573.9 x+5537.5$ & 0.9371 \\
\hline 11 & $\begin{array}{l}\text { Official reserves, billions of US dollars } \\
\text { (CEE) }\end{array}$ & $y=-0.0163 x^{6}+0.5972 x^{5}-8.302 x^{4}+54.807 x^{3}-177.51 x^{2}+275.16 x+87.562$ & 0.9714 \\
\hline
\end{tabular}

the world's reserve assets are allocated in the leading Asian countries (China, Japan, Hong Kong, South Korea, India, Singapore, and Thailand).

The total CEE countries' international reserves have increased by $71 \%$ over the analyzed period. However, the intra-regional distribution of international reserve assets is also uneven: over $64 \%$ of reserves are allocated in the Czech Republic and Poland (35.4\% and 29.1\%); Romania, Hungary, Bulgaria, and Croatia account for $10.5 \%, 7.8 \%, 7.1 \%$, and 5.0\%, respectively; other countries' shares do not exceed $1.4 \%$. Consequently, CEE countries differ substantially in terms of external solvency and thus have unequal monetary and financial capabilities to maintain the necessary economic security level to ensure its financial component.

Within the study framework, the relationship between global and regional indicators characterizing financial transformations affecting international security has been evaluated using economic and mathematical modeling of trends. Table 4 provides the trend models of global and regional financial indicators, based on which the smoothing of the time series of the studied indicators is made; model parameters are calculated using the tool "Data Analysis" of MS Excel. Based on the analysis of the coefficients of determination of the trend models given in Table 4, it can be concluded that the calculated models are reliable.
The next step in assessing the relationship between global and regional indicators that characterize financial transformations is calculating the approximate time-series growth rates to determine the relative speed of change in the direction of the indicators being studied (Figure 2).

Graphical analysis of the data presented in Figure 2 shows that:

- there is a direct relationship between global and regional indicators of the stock market capitalization dynamics over almost the entire analyzed period (the exception was the period of 2017-2018 when there was no visible relation between indicators; the emergence of such differences in dynamics is associated primarily with the huge increase in the stock market capitalization in the Czech Republic);

- global and regional indicators of debt securities dynamics move in one direction, the relationship between indicators is direct;

- there is no correlation between the dynamics of the world's bank assets and the Central and Eastern European countries;

- indicators of global and regional official reserves also move in different directions. 


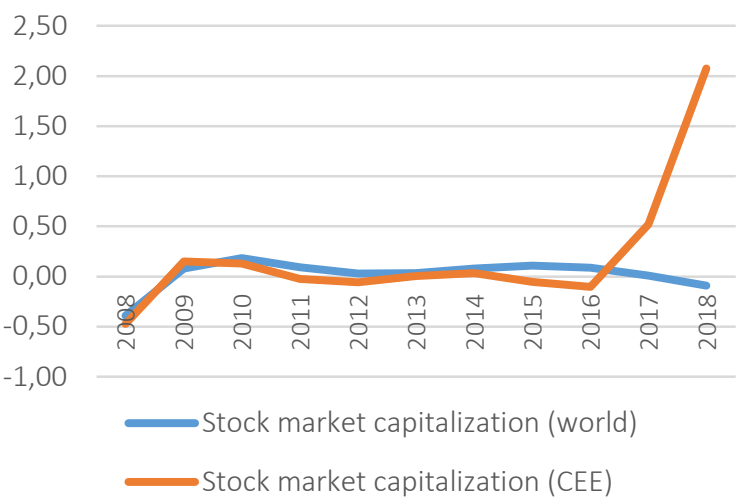

a) Stock market capitalization, USD billion

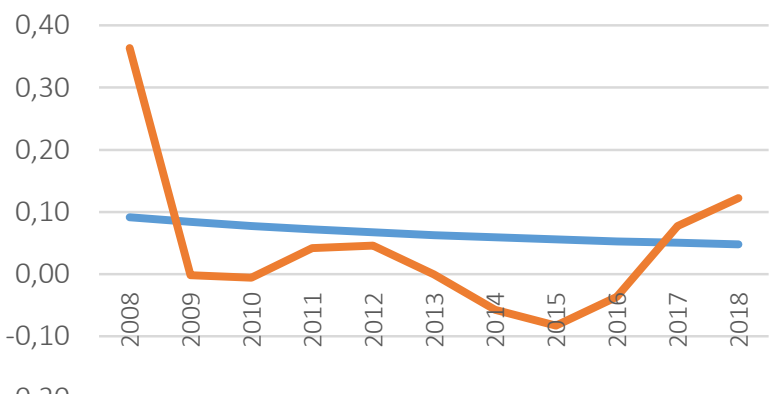

$-0,20$

Bank assets (world)

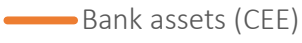

c) Bank assets, USD billion

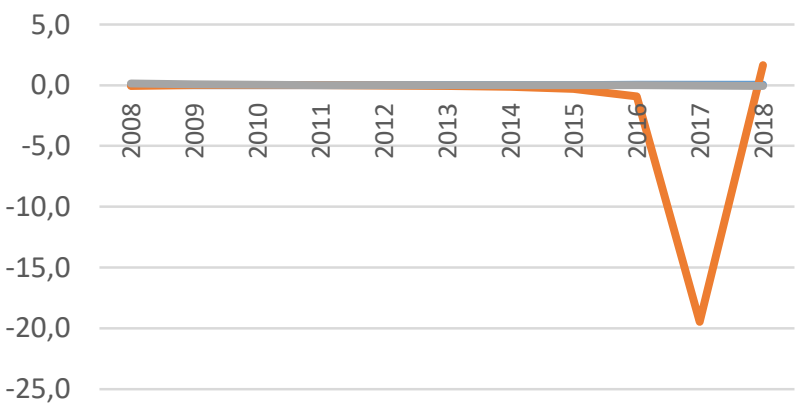

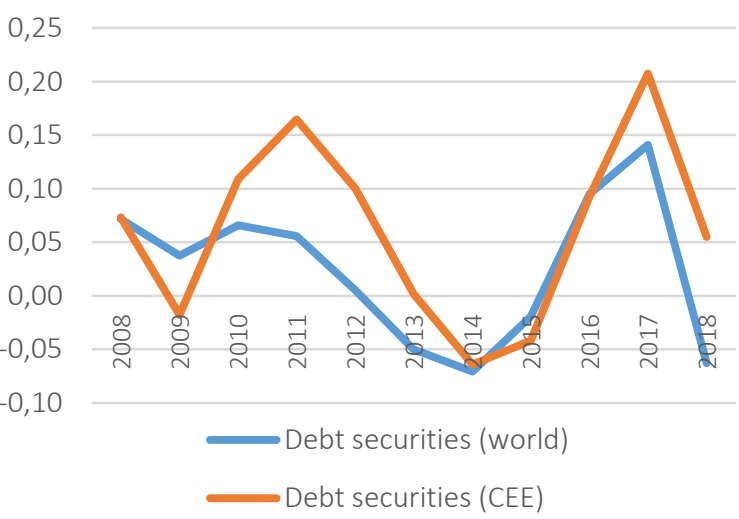

b) Debt securities, USD billion

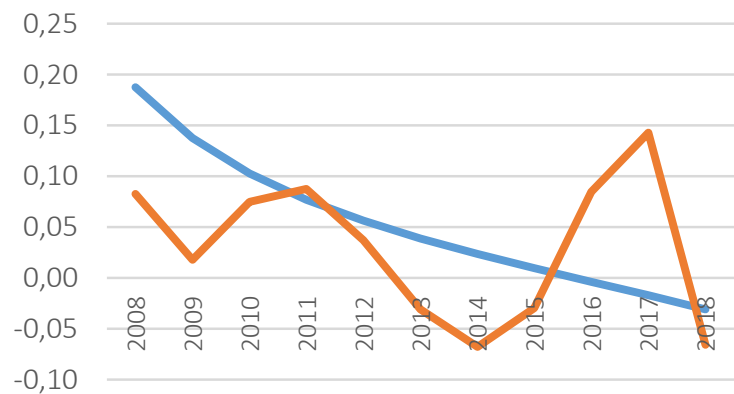

Official reserves (world) $\quad$ Official reserves (CEE)

d) Official reserves, USD billion

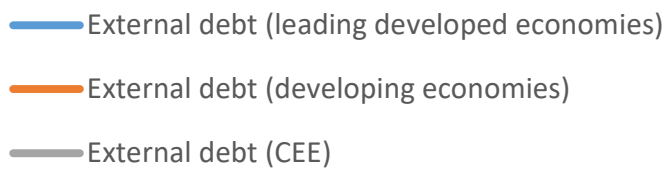

e) External debt, \% of GDP

Figure 2. Dynamics of growth rates of global and regional financial indicators for approximate data

The dynamics of the external debt ratio to GDP in the CEE countries almost completely corresponds to the similar average indicators in the group of leading developed countries; the relationship between the respective indicators of CEE and developing countries until 2016 had been direct; since 2016 there has not been any visible relationship. Thus, the results of assessing the relationship be- tween indicators that characterize the global financial transformations in the world and the CEE countries and affect the security environment, confirm the ambiguity of the CEE countries' positions in the global financial system and the dual nature of their financial sectors and markets that have characteristic features of both developed and emerging markets. 


\section{CONCLUSION}

Current global financial transformations, which influence economic security, are displayed in the increase in the level of financial depth; the development of the global financial crisis; the increasing uncertainty in the global financial environment; growing unevenness in the spatial distribution of global financial assets; instability of the structure of global financial assets by type of financial instruments; aggravation of external debt problems; increasing heterogeneity of countries' international liquidity, etc. The region of Central and Eastern Europe so far does not play a significant role in the redistribution of the world's financial resources. Moreover, the CEE countries' shares in the global financial assets are lower than the CEE countries' share in world production. However, it shows that the countries' financial sectors are less subject to crisis "contagion", contributing to their economic security. The level of financial development of the region also lags behind the indicators of the world economy's financialization. The relatively low CEE financial depth levels indicate that national economies are less likely to form financial "bubbles" and suffer financial shocks. The region's share in the global reserves exceeds $3 \%$, outpacing its share in the global financial assets and ensuring the countries' international liquidity.

The structure of CEE countries' financial assets corresponded to the structure of global financial assets in the pre-crisis period and the first years after the crisis. Today there are significant differences between these structures: in the world, bank assets account for more than half of financial assets, while shares of stock and debt securities are declining. In CEE countries, against the background of a decline in the share of bank assets and debt securities, there is a rapid increase in the share of stock market capitalization (up to 40\%). The intra-regional distribution of CEE financial assets is highly concentrated: about $78 \%$ of the financial assets are allocated in Poland, the Czech Republic, and Hungary, which is an indicator of the countries' financial development's heterogeneousnature and their ambiguous positions in the global financial system. CEE countries are also significantly differentiated in terms of external debt levels and the dynamics of external debt indicators. The average external debt to GDP ratio of the CEE group is lower than in most of the leading developed economies. The external solvency of the CEE countries is generally improving, which is reflected in the growth of their international reserves. Simultaneously, official reserves are unevenly distributed: nearly $90 \%$ of the reserves are concentrated in five countries (the Czech Republic, Poland, Romania, Hungary, and Bulgaria), which is an evidence of the high international liquidity heterogeneity of the region.

The trajectory of the region's financial trends compared to the world indicators is also ambiguous. The dynamics of stock market capitalization and debt securities of the CEE countries almost completely fit the corresponding world indicators' dynamics. The global and regional official reserves and bank assets are moving in different directions. The dynamics of CEE external debt indicators and the corresponding average indicators in leading developed countries are almost identical. The considerable heterogeneity of the CEE countries' financial development remains a significant problem. Stock market capitalization indicators are characterized by great volatility, external debt burden continues to rise in half of the countries of the region, and official reserves are distributed too unevenly, which should be taken into consideration when identifying major threats affecting the security environment of CEE countries and developing relevant policy and strategy for ensuring the economic security of the region.

\section{AUTHOR CONTRIBUTIONS}

Conceptualization: Olena Bulatova, Yurii Chentukov, Tetyana Marena.

Data curation: Tetiana Shabelnyk, Tetyana Marena.

Formal analysis: Tetiana Shabelnyk, Tetyana Marena.

Investigation: Olena Bulatova, Yurii Chentukov, Tetiana Shabelnyk, Tetyana Marena.

Methodology: Olena Bulatova, Tetiana Shabelnyk,

Project administration: Olena Bulatova, Yurii Chentukov. 
Supervision: Olena Bulatova.

Validation: Yurii Chentukov, Tetiana Shabelnyk.

Visualization: Tetiana Shabelnyk, Tetyana Marena.

Writing - original draft: Yurii Chentukov, Tetyana Marena.

Writing - review \& editing: Olena Bulatova, Yurii Chentukov.

\section{REFERENCES}

1. Balling, M., Lierman, F., \& Mullineux, A. (2004). Financial markets in Central and Eastern Europe: stability and efficiency. London: Routledge. Retrieved from https://www.suerf.org/ books-and-colloquium-volumes/2067/financial-marketsin-central-and-eastern-europestability-and-efficiency

2. Bank for International Settlements. (n.d.). Debt securities statistics. Retrieved from https:// www.bis.org/statistics/secstats. htm? $\mathrm{m}=6 \% 7 \mathrm{C} 33 \% 7 \mathrm{C} 615$

3. Bayar, Y., Akyuz, F., \& Erem, I. (2017). Openness and financial development in Central and Eastern European countries. Studies in Business and Economics, 12(3), 5-16. https://doi. org/10.1515/sbe-2017-0032

4. Bocka, B., Jocic, J., Petrovics, A., \& Tsanov, R. (2007). Security threats and responses in Central Europe. Retrieved from https:// csis-website-prod.s3.amazonaws. com/s3fs-public/legacy_files/files/ media/csis/events/070402_ceereportfile.pdf

5. Buzan, B. (1991). People, states \& fear: an agenda for international security studies in the postcold war era. London: Pearson Longman.

6. CEIC Data. (n.d.). Indicators. Retrieved from https://www. ceicdata.com/en/indicators

7. Cevik, N. K., Dibooglu, S., \& Kutan, A. M. (2016). Real and financial sector studies in Central and Eastern Europe: a review. Journal of Economics and Finance, 66(1), 2-31. Retrieved from https://www.researchgate.net/ publication/298072702_Real_ and_financial_sector_studies_in_ central_and_Eastern_Europe_A_ review
8. Dudin, M. N., Fedorova, I. J., Ploticina, L. A., Tokmurzin, T. M., Belyaeva, M. V., \& Ilyin, A. B. (2018). International practices to improve economic security. European Research Studies Journal, 21(1), 459-467. Retrieved from https://www. ersj.eu/dmdocuments/2018 XXI_1_38.pdf

9. Gardó, S., \& Martin, R. (2010). The impact of the global economic and financial crisis on Central, Eastern and South-Eastern Europe: A stock-taking exercise. Frankfurt: European Central Bank.

10. Global Economy. (n.d.). Business and economic data for 200 countries. Retrieved from https:// www.theglobaleconomy.com

11. Herd, G. P., \& Aldis, A. (2005). Soft Security Threats \& Europe. London: Routledge.

12. International Monetary Fund. (n.d.). World Economic Outlook Database. Retrieved from https:// www.imf.org/external/pubs/ft/ weo/2019/01/weodata/index. aspx

13. Matousek, R. (2010). Money, banking and financial markets in Central and Eastern Europe. London: Palgrave Macmillan. Retrieved from https://www. amazon.com/Banking-Financial-Markets-Central-Eastern/ $\mathrm{dp} / 1349312118$

14. Ministry of National Defence of Poland. (n.d.). Security environment of Poland today and in 15 years. Retrieved from https://www.gov.pl/web/ national-defence/security-environment-of-poland-today-andin-15-years

15. Organization for Economic Cooperation and Development. (n.d.). Glossary of Statistical Terms: Central and Eastern European Countries (CEECS). Retrieved from https://stats.oecd. org/glossary/detail.asp?ID=303

16. Orylski, O. (2009). Central and Eastern European capital market's development possibilities. Economics \& Sociology, 2(2), 46-53. https:// doi.org/10.14254/2071789X.2009/2-2/4

17. Parakhonskyi, B. O., Yavorska, H. M., \& Reznikova, O. O. (2013). Mizhnarodne bezpekove seredovyshche: vyklyky $i$ zahrozy natsionalnii bezpetsi Ukrainy [International security environment: challenges and threats to Ukraine's national security] (56 p.). K.: Natsionalnyi instytut stratehichnykh doslidzhen. (In Ukrainian)

18. Redo, M. (2018). Comparison of external exposure of Central and Eastern-European states as a factor threatening financial security of their economies. Historia i Polityka, 24, 135159. https://doi.org/10.12775/ HiP.2018.017

19. Schröder, M. (2001). The new capital markets in Central and Eastern Europe. Berlin, Heidelberg: Springer-Verlag.

20. Shkarlet, S., Dubyna, M., Vovk, V., \& Noga, M. (2019). Financial service markets of Eastern Europe: a compositional model. Economic Annals-XXI, 176(3-4), 26-37. https://doi.org/10.21003/ ea.V176-03

21. Silvestri, R. (2019). Unlocking the potential of capital markets in Central and Eastern European countries. CFA Institute Market Integrity Insights. Retrieved from https://blogs.cfainstitute. 
org/marketintegrity/2019/01/29/ unlocking-the-potential-ofcapital-markets-in-central-andeastern-european-countries/

22. Świeżak, P. (2012). International challenges for regional security in Central and Eastern Europe - Poland, the EU and protracted conflicts. Retrieved from https:// fas.org/man/eprint/aurora_29/ part03.htm

23. Tumkevič, A. (2016).

Cybersecurity in Central Eastern
Europe: from identifying risks to countering threats. Baltic Journal of Political Science, 5, 73-88. https://doi.org/10.15388/ BJPS.2016.5.10337

24. UNCTADstat. (n.d.). Official website. Retrieved from https:// unctadstat.unctad.org/EN/

25. World Bank Group. (2019). International Debt Statistics 2020. Retrieved from https:// openknowledge.world- bank.org/bitstream/handl e/10986/32382/9781464814617. pdf? sequence $=7$ \&isAllowed $=y$

26. World Bank Group. (n.d.). World Bank Open Data. Retrieved from https://data.worldbank.org/

27. World Economic Forum. (2019). The Global Risks Report 2019. Geneva: World Economic Forum. Retrieved from https://www. weforum.org/reports/the-globalrisks-report-2019 